\title{
UTILIZATION OF A DEVELOPED SOLAR STORAGE AND DRYING SYSTEM FOR CONTINUOUS DEHYDRATION OF SOME LEAFY MEDICINAL PLANTS
}

\author{
Baher M. A. Amer*
}

\begin{abstract}
A developed solar system was used for dehydration some leafy medicinal plants and for storage of solar energy in water. It consisted of a flat-plate collector, a reflector, a drying unit, an auxiliary electric heater and a water tank. The solar system was tested during June to September 2009 for drying Lemon balm (Melissa officinalis L.) and peppermint (Mentha pepperita). Inlet air temperature to the dryer was higher than the ambient temperature and it could be maintained as desired using a temperature controller. Drying was taken about 8 to 10 hours to reduce the moisture contents of Melissa from 70-72 to 9\% (wb) and 33 hours to reduce it from 70-72 to $17 \%$ (wb) by the hybrid dryer and natural sun drying method, respectively. Moisture content of Peppermint was reduced from $69-71 \%$ (wb) to 8-9 \% (wb) in 10-12 hours by hybrid dryer and 51 hours by natural sun drying to reduce the moisture contents of it to $10 \%(\mathrm{wb})$. The capacity of the dryer was to dry about 16-20 kg of fresh Lemon Balm and also about 16-20 kg of fresh Peppermint per batch for each plant. The color, oil content and appearances of the products dried in the hybrid dryer were better than sun drying method.

The dryer was also occupied with an auxiliary heat source to be used whenever adverse weather conditions exist. Using the water tank, about $15-20^{\circ} \mathrm{C}$ can be maintained in water during the time of sun-shine. During night time, the stored head is transferred from the water to the drying air inside the solar dryer and controls the air temperature through the drying process at night.
\end{abstract}

\section{INTRODUCTION}

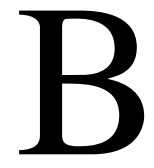

oth lemon balm and peppermint are consider as very important medicinal plants. Lemon balm (Melissa officinalis L.) is a perennial herb of the family Lamiaceae, cultivated for the characteristic lemon-scented leaves. Peppermint (Mentha pepperita) is genus of the Labiatae family.

*Lec., Agric. Eng.; Fac. of Agric.; Cairo University-Egypt 
They are used for several purposes in food, pharmaceutical and cosmetic industries due to its flavoring, medicinal and therapeutic properties.

Nedkov and Georgiev (1991) stated that M. piperita is a major essential oil plant. Dried leaves are used for various blends of tea which are reputed to have medicinal properties. The most common technique for processing and marketing of medicinal plants is by hot air drying in order to reduce the moisture content to a level for safe storage according to Müller and Heindl (2006) and Kassem et al. (2006). However, improper application of the drying method affects quality characteristics such as color.

Usually, when the herb is used as seasoning or tea the color of the leaves is of prime importance to the consumer as product quality criterion and consumer prefers leaves with natural green color.

Color is considered to play a significant role in determining the quality of food materials since it has a great influence on their appearance, processing and acceptability. Dried lemon balm leaves exhibit insufficient color quality as compared to the fresh ones. During hot-air drying the discoloration in leaves from bright green to pale green occurs mainly due to loss of chlorophyll which is sometimes accompanied by browning.

Drying of crops in the most countries in tropical and subtropical regions is normally carried out by traditional sun drying method. Although sun drying offers a cheap and easy method of drying but the drying rate is very slow and it often results in inferior product quality due to dependence of weather conditions and vulnerability to be attacked and contaminated with insects, pests, microorganisms, dust, and dirt. In addition, adverse weather exits and the products are infected by insects and microorganisms and these infected products become causes of serious health hazards. When a continuous adverse weather exists for a couple of days, then the whole amount of products are spoiled (Bala, 2000). Therefore, an effective attempt has to be taken to protect the food losses, especially during the adverse weather conditions.

As an alternative to sun drying, solar drying is a promising alternative for crop drying in developing countries, because mechanical drying is mainly used in industrial countries and is not visible for small farms in developing countries due to high investment and operation costs 
(Mühlbauer, 1986). Solar energy for crop drying is environmentally friendly and economically viable in developing countries (Esper and Mühlbauer, 1998). Different types of solar dryers have been developed and tested in different regions of the tropics and subtropics (Ghazanfari et al., 2003; Hossain and Bala, 2007). Some researches for solar drying of herbs were conducted, (Awady et al., 1993; Abdel-Galil and Tarhuni, 2005).

Hybrid solar dryer is one in which drying is continued in off sun shine hours by back up heat energy or storage heat energy. Therefore drying is continued and product is saved from possible deterioration by microbial infestation during off sunshine hours and adverse weather (Hossain $\boldsymbol{e t}$ al., 2008). Bennamoun and Belhamri, (2003) reported that significant improvement was registered after the heater is added to the solar dryer during periods of low sunshine. Variability and time-dependent characteristic of solar radiation make storage necessary for continuous operations for the drying food process (Miller, 1983). Storage and auxiliary supply can be used to assess compatibility of solar energy to meet the drying process temperature, Singh et al., (1983).

Ghanem (1998) indicated that using a solar collector and energy storage system with water and automatic control of stored water temperature and an electrical heater (Hybrid) permitted almost uniform drying during both day and night hours. The results show that excellent quality dried vegetables and fruits may be obtained using an appropriately designed solar dryer which permitted continuous drying throughout daylight and at night hours.

The most common materials used for heat storage are water, oil, rocks and concrete blocks. The absolute density of most stones, bricks or concrete type materials ranges from 1600 to $2500 \mathrm{~kg} / \mathrm{cm}^{3}$. The specific heat of these materials ranged from 0.71 to $0.90 \mathrm{~kJ} / \mathrm{kg} .{ }^{\circ} \mathrm{C}$, however for water is $4.18 \mathrm{~kJ} / \mathrm{kg} .{ }^{\circ} \mathrm{C}$.

The heat storage capacity/unit volume of these materials ranges from 1136 to $2250 \mathrm{~kJ} / \mathrm{m}^{3}{ }^{\circ} \mathrm{C}$, (Maria, 1977). Improving the limestone bed thermal behavior may be maintained by keeping the airflow rate as low as possible and increasing the bed height. The ratio of the heat capacity of the rocks to that of the fluid must be kept as high as possible by 
increasing the thermal capacity of the storage media. So, more solar energy could be stored. The rock bed tended to decrease the temperature fluctuation of solar heated air around the mean temperature. It is working as a heat exchanger, since it tends to damp the temperature oscillations and smooth down irregularities of the air temperature profile (AbdelGhaffar, 1986).

Paakkonen et al. (1999) carried out some drying experiment on Mentha piperita, and some other plants (grown in Finland) were conducted using infrared drying, operating at a product temperature of $35-50^{\circ} \mathrm{C}$ and oven drying at $40^{\circ} \mathrm{C}$. The essential oil content, composition and residual water content of the dried herbs were determined. The microbiological quality of fresh and dried material was determined for total bacterial count, moulds and yeasts. Fresh material had very poor microbiological quality. Drying method did influence microbiological quality, but no trends were determined. However, the quality of the fresh material was the major factor determining the quality of dried herbs.

This paper presents the performance of a hybrid solar dryer connected to storage water tank suitable for drying continuously of lemon balm and peppermint comparing to sun drying. In addition, this study was conducted to test the effect of sun and solar drying on the essential oil content and composition of lemon balm and peppermint.

\section{MATERIALS AND METHODS}

\section{A. Plant material}

Fresh plants of lemon balm and peppermint were collected from an organic farm at Thüringen (Germany) in June, July and August 2009. Prior to drying experiments, the leaves and the stalks were dried. The moisture content of lemon balm plant, (wet basis) was ranged from 70 to $75 \%$, whereas the moisture content of peppermint plant, (wet basis) was ranged from 69 to $72 \%$.

\section{B. Description of the hybrid solar drying system}

A solar assisted hybrid dryer was designed and fabricated at at Institut fur Agrartechnik Potsdam-Bornim, Germany (Amer, 2006). This dryer was used for drying banana slices with a good quality (Amer et al., 2010). 
The dryer basically consisted of a solar collector, a reflector and a drying unit. A photo and schematic view of the solar assisted hybrid dryer is shown in Figures 1 and 2. A brief description of each unit is given below.

\section{The solar collector :}

Sabbah et al. (1999), studied the influence of the collector length under three levels of air flow rates on the thermal efficiency of plastic and glass solar collector. When the length of collectors increased, the thermal efficiency decreased.

Therefore the dimensions of the solar collector were established to be not long in length. It was $2.80 \mathrm{~m} \times 1.80 \mathrm{~m}$. It consisted of transparent cover, absorber plate, heat exchanger and insulation. The transparent cover of the collector was $4 \mathrm{~mm}$ thick clear glass supported by $60 \mathrm{~mm}$ wooden frame. A corrugated iron sheet painted in black about $200 \mathrm{~mm}$ below the glass cover was used as an absorber plate.

To increase the efficiency of the solar collector, flat type reflector made of glass mirror was hinged at top of the solar collector, however using reflectors increased both heat collection efficiency and air temperaturerise by about 50\%, (Sabbah, 1986). The dimensions of the reflector were the same as those of the solar collector so that it could be used as a reflector in day time and as a cover in night time or in adverse weather. This reflector had adjustable angles that could be changed according to the change of the sun's angle during the day to collect higher amount of sun rays that fall down on the solar collector. The collector was placed on 6 legs with $150 \mathrm{~mm}$ wheel to turn the solar collector horizontally and change its direction according to the change of the sun's angle. The solar collector was insulated by $50 \mathrm{~mm}$ thick polystyrene. A radial fan operated by a $0.75 \mathrm{~kW}, 220 \mathrm{~V}$ an electric motor was connected at one side of the collector.

There were three air controllers at the inlet, outlet, and just before the suction opening of the air blower to control the air flow at the inlet, outlet and mixed air. These air controllers could be controlled manually using three switches according to the quantity and the velocity of air needed using a small motor fixed on each controller. The motors can be opened or closed using a special electric key exists on an electric board fixed at the end of the solar drying unit. 

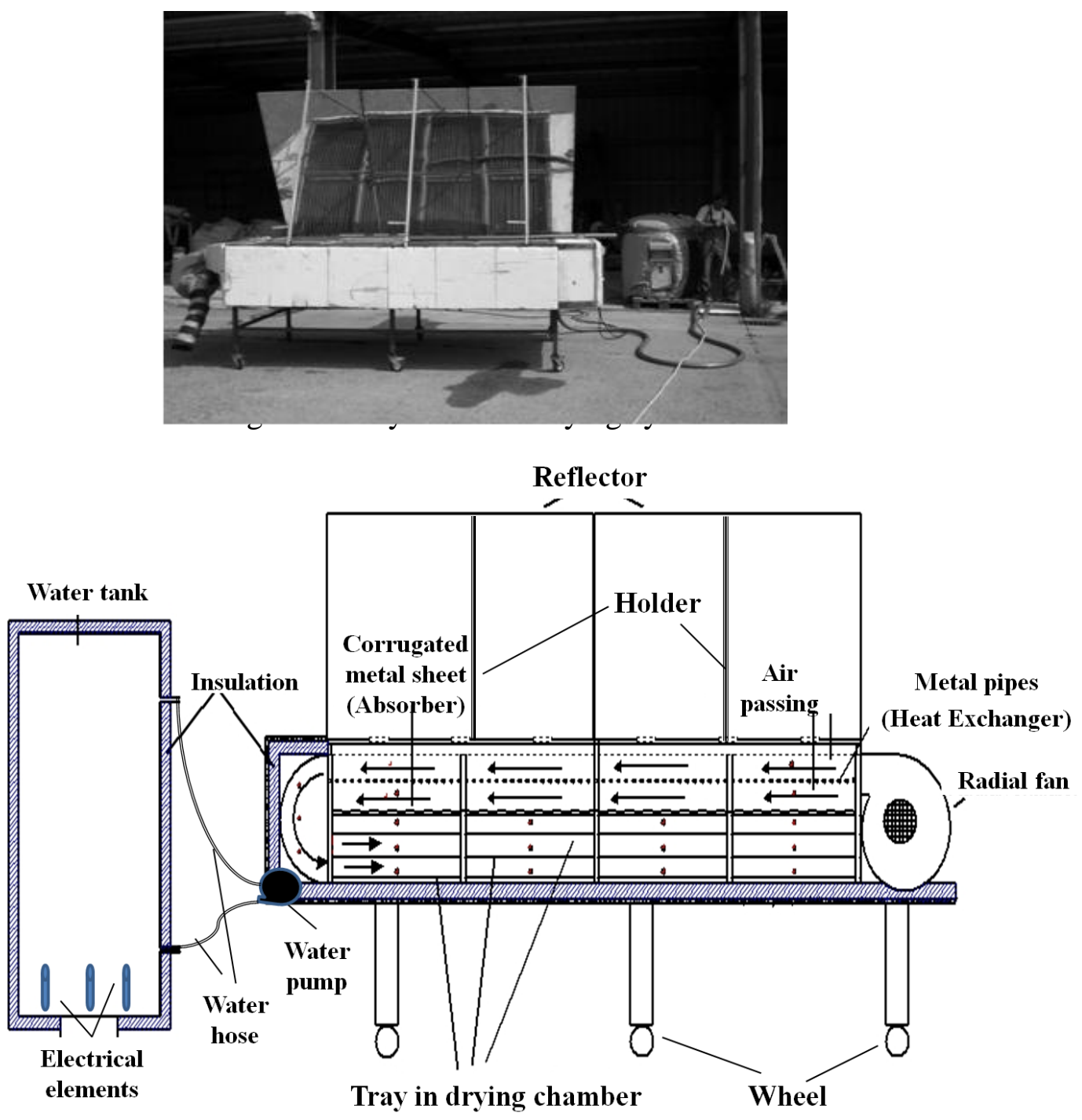

Fig. 2. A Schematic view of a solar system for drying and storage energy.

\section{The drying chamber :}

The length and width of the solar dryer were same as the collector $(2.80$ $\mathrm{m} \times 1.80 \mathrm{~m}$ ). It was located directly under the solar collector and $200 \mathrm{~mm}$ under the absorber plate. It was divided into 8 parts with equal dimensions. In each of the part there were 2 trays for drying. This allows the usage of 16 drying trays in the drying unit. The drying air is passed across the fruits spread in thin layers on 16 horizontally stacked trays and 
arranged in two vertical columns. Each tray was made of wooden frame and plastic net with dimensions of $900 \mathrm{~mm} \times 70 \mathrm{~mm}$. The drying air was heated up in the solar collector and passed to the drying chamber through a curved metal part at the end of the solar drying unit. This curved metallic part had a shape of a half horizontal cylinder with the same width and height of the solar collector and the dryer. Through this curved part, the direction of the air could be changed inside the solar drying unit. The drying air came from the solar collector through curved part to the opposite direction and turning towards the drying unit and flew over and under all the drying trays before exhausting from the outlet. To increase the efficiency of the solar drying unit, some parts of the hot air was mixed with the fresh air at the end of the solar dryer and flew through the collector again to the solar drying unit instead of exiting through the outlet opening. There were three air controllers at the inlet, outlet, and just before the suction opening of the air blower to control the air flow at the inlet, outlet and mixed air. The three air controllers could be controlled manually using three switches according to the quantity and the velocity of air needed using a small motor fixed on each controller. The motors could be opened or closed using a special electric key on an electric board fixed at the end of the collector.

\section{Cross-flow heat exchanger and heat storage unit :}

The heat exchanger consisted of a $15 \mathrm{~mm}$ diameter copper tubes placed inside the solar collector, $100 \mathrm{~mm}$ below the glass and $100 \mathrm{~mm}$ above the absorber plate. The heat exchanger consisted of 70 tubes covered the whole area of the drying collector. These tubes were fixed and put over a metal holder of width $20 \mathrm{~mm}$ at each side of the solar collector. Two end $\mathrm{s}$ of the copper tubes were connected to the water storage tank with 15 $\mathrm{mm}$ plastic tubes. The capacity of the water tank was 500 litres. Water flew from water tank and circulated through the plastic and copper tubes by a small water pump of capacity $20 \mathrm{Lit} / \mathrm{h}$. The heat exchanger gave a part of the heat collected during the hours of the sun shine, which was carried by air inside the solar collector, to the water inside the copper tubes. The water passed very slowly inside the pipes to be able to take the largest part of heat carried in the air contact with the external surface of 
the tubes. This water was stored inside a plastic tank of 500 litre volume and insulated by $50 \mathrm{~mm}$ fibre-glass. The heat stored during the day in the water tank could be used again at night. The temperature of this water could be raised by using $6 \mathrm{~kW}$ water heaters located inside the tank to reach a desired temperature for drying during the night and for maintaining the temperature and the humidity throughout the drying process.

\section{Experimental Procedure}

Several experimental run for solar and sun drying of Lemon Balm and Peppermint were carried out during the period of June to August 2009. Fresh and uniform size of Lemon Balm and Peppermint plants were dried in the solar dryer as well as in open sun, Figures 3 and 4. Before starting an experimental run, the whole apparatus was operated for at least one hour to stabilize the air temperature and air velocity in the dryer.

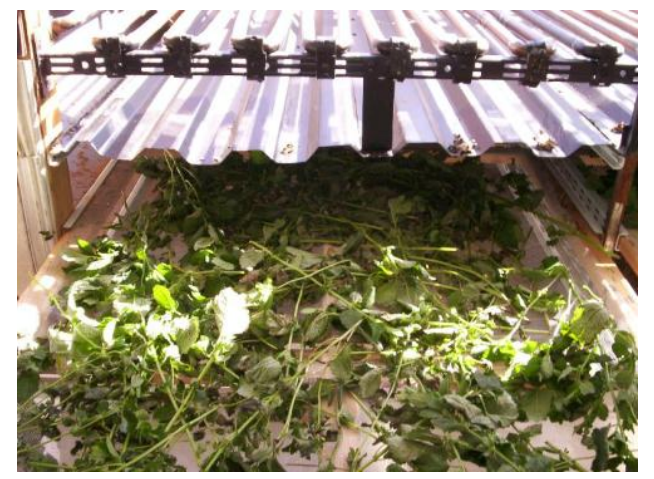

Fig. 3. Fresh Lemon Balm put over tray in the solar dryer

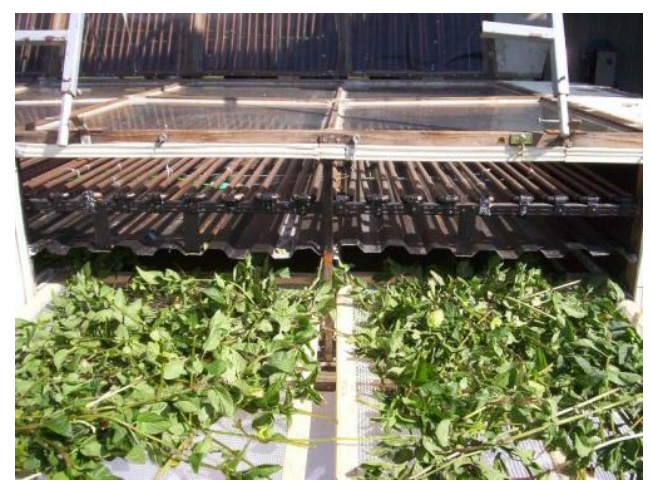

Fig. 4. Fresh Peppermint put over tray to dry in the solar dryer 
Drying was started after completion of loading, usually at 10. a.m. and continued up to reach the final moisture content of the product. Weight loss of both the samples in the dryer and the control samples in the open sun were measured during the drying period in day time (10 a.m. to 19:00 h) at one hour interval with an electronic balance. During the day time, the positions of the collector and its reflector were adjusted with the solar angle so that maximum solar radiation could be captured by the solar collector as well as by the reflector. In the afternoon, after 19:00 h, the samples in the dryer were kept in the dryer and the collector was covered by reflector and the control samples were kept in the room. Next morning, then the water in the storage tank begin to transfer the heat to air inside the drying unit until the sun-shine and the temperature of water in the tank keep staple during the night period by using electrical heating elements.

At 10 a.m., the cover of the dryer was removed and subjected to dry the samples by solar radiation. The control samples were put in the sun as well. The ambient air, collector air, drying air (on different trays), inlet air and outlet air temperatures were measured at one hour interval by a digital temperature meter. A digital solar meter was used to measure the global solar radiation during the day time drying period. Velocity of drying air was measured with an anemometer. The moisture contents of the samples were measured by drying the samples in an air ventilated oven at $105^{\circ} \mathrm{C}$ for 24 hours (Hossain et al., 2007). After completion of drying, the dried samples were collected, cooled in a shade to the ambient temperature and then sealed it in the plastic bags.

\section{Measurement of oil content and chlorophylls "a" and " $b$ " contents:}

All experimental procedures were performed in triplicate were given by Food Chemistry Institute, Berlin University of Technology, Berlin Germany. Extraction oil from the fresh and the dried samples with diethyl ether for $24 \mathrm{~h}$. Chlorophylls a and b contents were determined by Antioxidants activity of diethyl ether extract (Antiradical effect against 1,1-diphenyl-2-picrylhydrazyl "DPPH" free radicals, \% Inhibition after $30 \mathrm{~min})$. 


\section{RESULTS AND DISCUSSION}

\section{A. Dryer performance}

Variations of ambient air temperature, dryer air temperature, solar radiation with times of a day are shown in Fig. 5. It is observed from the Figure that ambient temperature and solar radiation varied with time of a day and these were found to reach the peak between 11:00 a.m. and 13:00 p.m. But the drying air temperature was maintained constant at $47 \pm 1^{\circ} \mathrm{C}$ using temperature controller and adjusting airflow by a regulator.

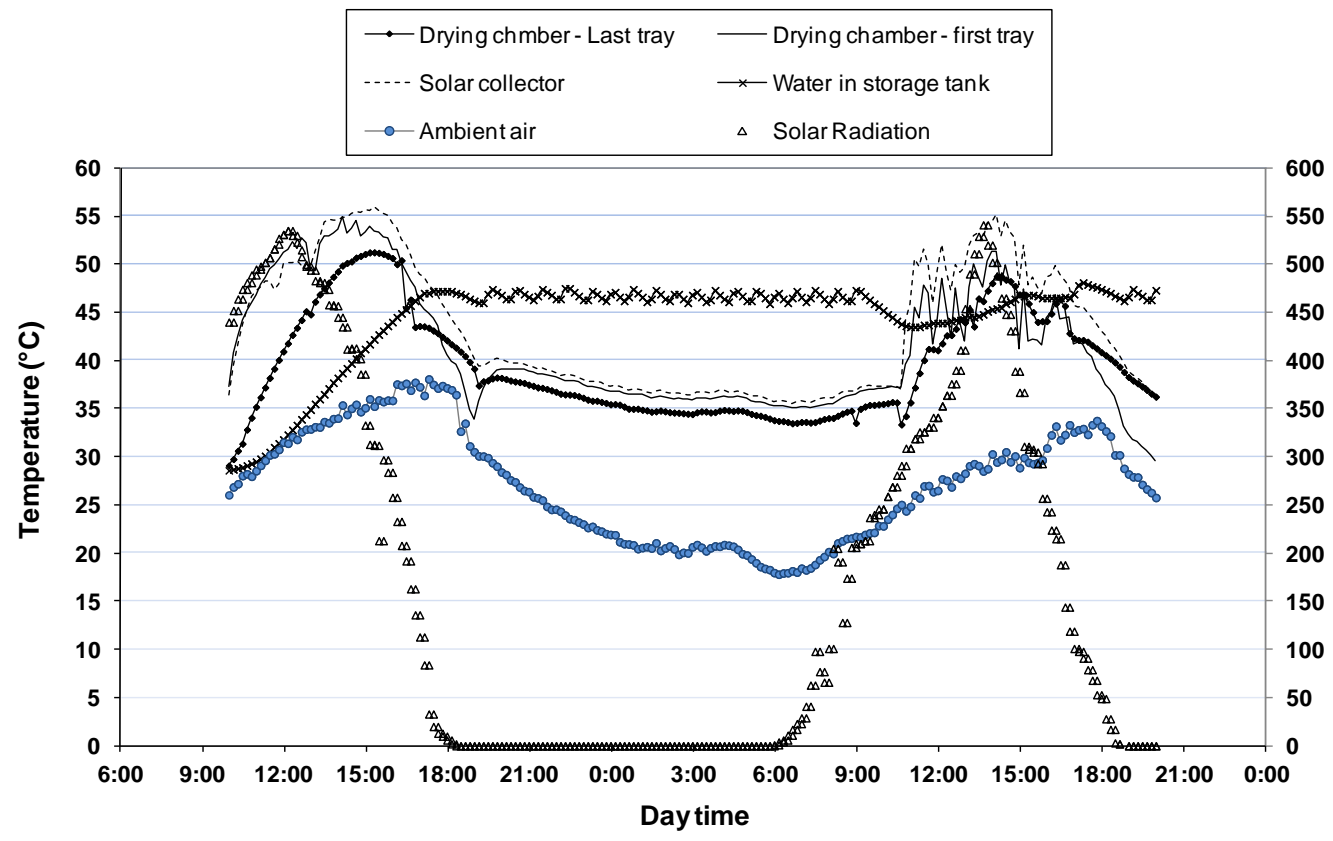

Fig.5. Variations of ambient air temperature, dryer air temperature, solar radiation with times of a day at drying of Lemon Balm.

Constant temperature is very important to maintain equal thermal stress on the product for its quality. Reflected solar radiation was found about $57 \%$ of global solar radiation. This radiation was added to the solar collector to increase its efficiency.

When water was going through in the collector (heat exchanger) from the water tank, then water was heated along with the air in the collector and stored in the water tank. By this way water temperature rose up and this hot water may be recirculated at night for heating the air in the collector. 
Variation of air and water temperatures with solar radiation for water flow in a typical sunny day is shown in Fig.5. At the end of the day (afternoon) water temperature in the water tank increased above $40^{\circ} \mathrm{C}$ from initial morning temperature of about $15^{\circ} \mathrm{C}$. In this drying system, collector and drying chamber temperatures were little lower than those of collector heating without water flow but not below the desired temperature $\left(40-50^{\circ} \mathrm{C}\right)$.

The drying for peppermint could be conducted at night by using electric heaters for keeping the water temperature inside the tank at $40^{\circ} \mathrm{C}$ during night time and at low intensity of solar radiation in the morning of next day after sun-shine. In this case, the heat was transferred from the water to air through the heat exchanger to keep the air inside the drying chamber around $30^{\circ} \mathrm{C}$, then the drying time was extended to 22 hours, Fig. 6 .

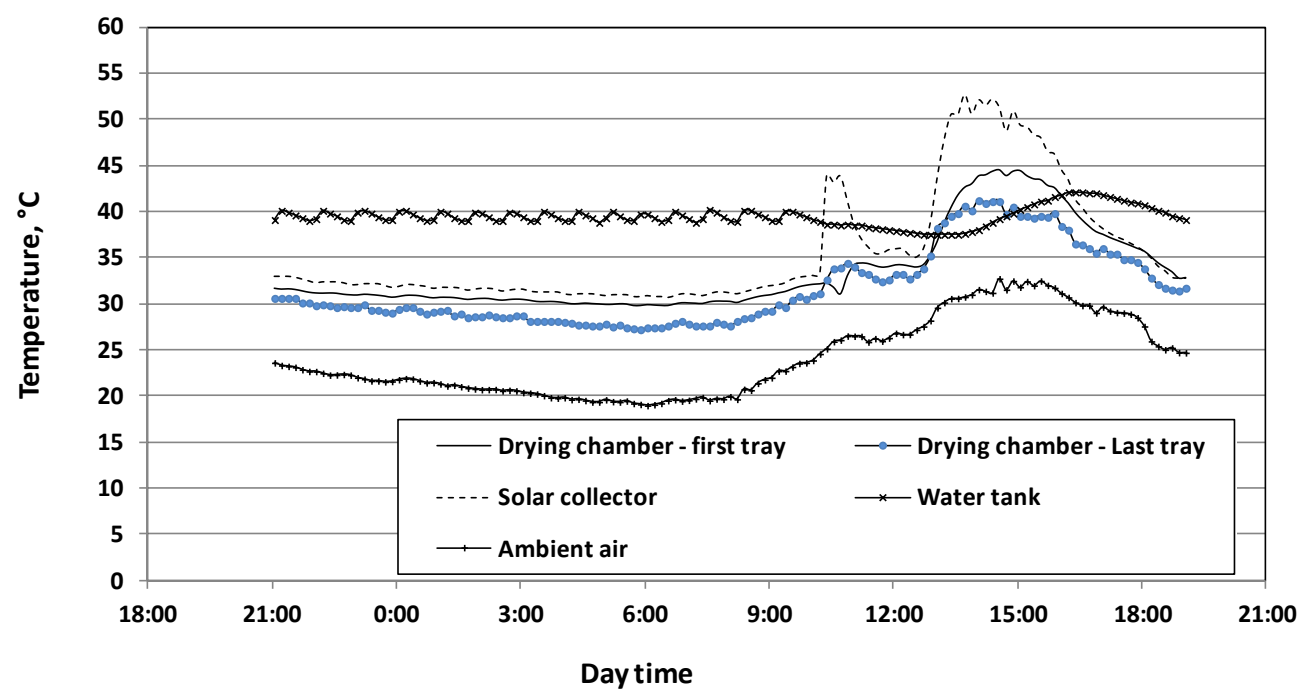

Fig.6. Variations of ambient air temperature, dryer air temperature and air collector at drying of peppermint starting drying at night.

Fresh Lemon Balm (Melissa) and peppermint were carried on the drying trays in the hybrid solar dryer, Figs. 7 and 8. 


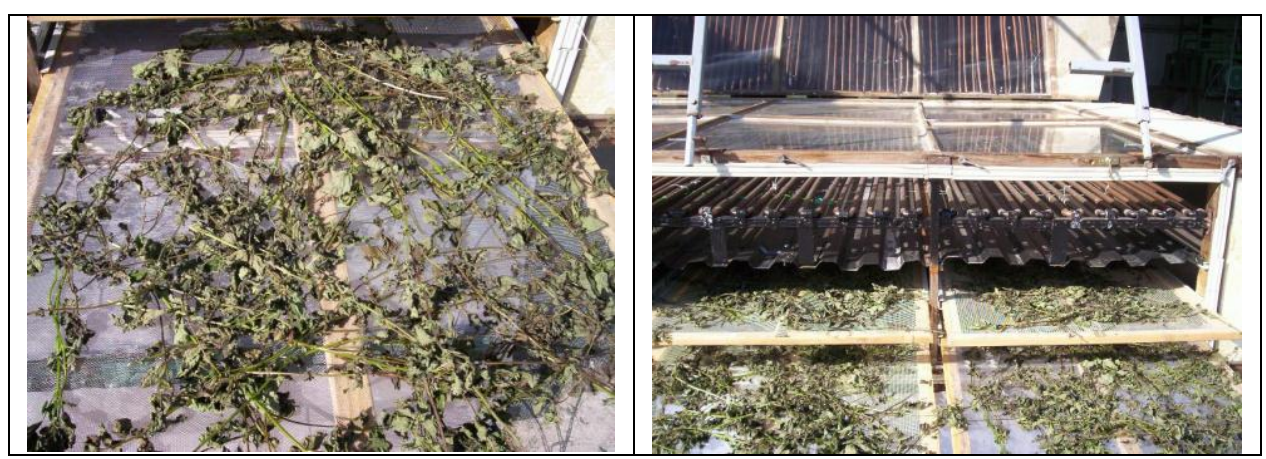

Fig. 7. Dried Lemon Balm put over tray in the solar dryer

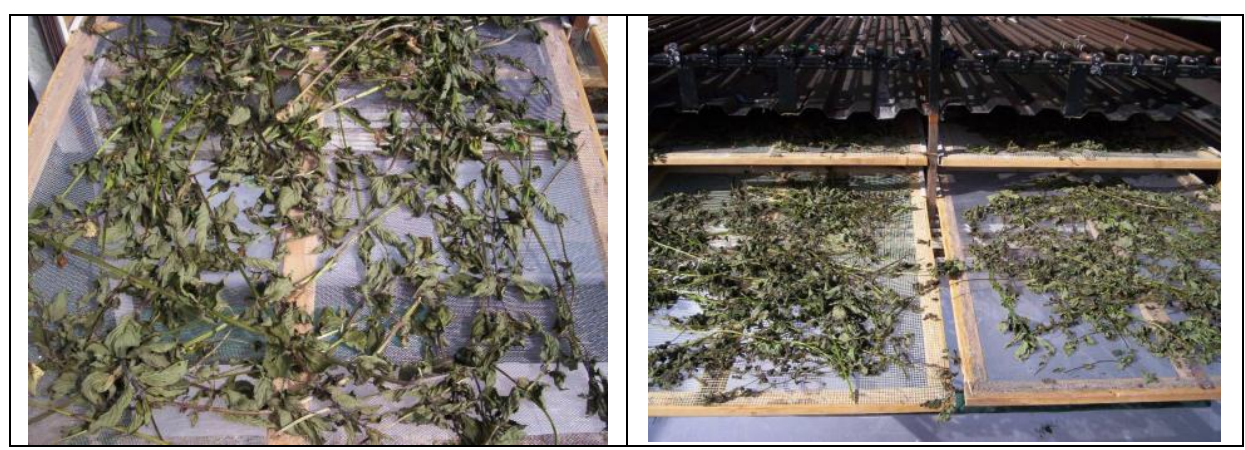

Fig. 8. Dried Peppermint put over tray in the solar dryer

The drying performance of Melissa in the dryer and in the open sun is shown in Fig. 9. It is observed from the Figure that moisture reduction was higher in solar dryer than that of open sun drying. It took about from 8 to 10 hours to reduce the moisture content from 72 to $9 \%$ (wb) in the dryer. On the other hand, sun drying method took about 33 hours to reduce the similar moisture content. The loading capacity of dryer was about $16-20 \mathrm{~kg}$ of fresh lemon balm per batch.

Drying performance of Peppermint samples are shown in Fig. 10. Moisture content of Peppermint was reduced from $69-71 \%$ (wb) to 9-11 $\%$ (wb) in 12 hours by solar and sun drying respectively in 51 hours. The loading capacity of dryer for drying of fresh Peppermint was about 16-20 kg per batch. 


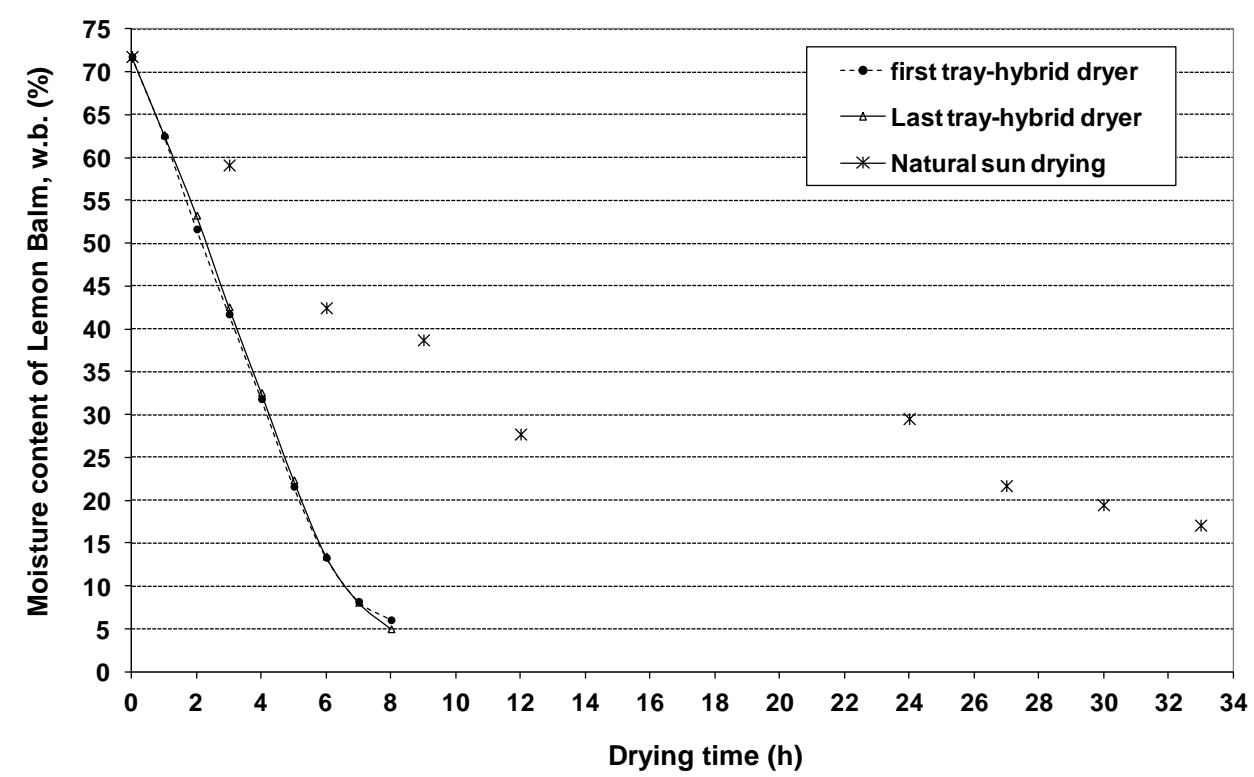

Fig. 9. Solar drying and sun drying of lemon balm.

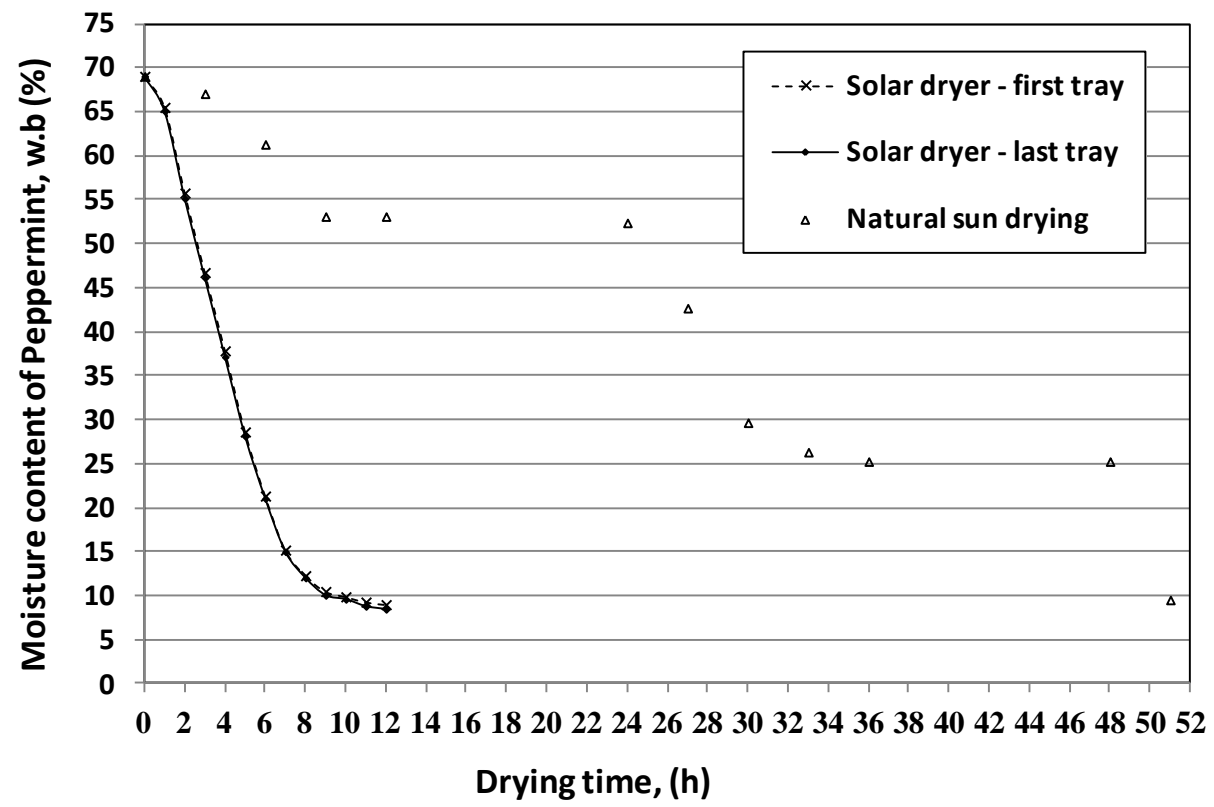

Fig. 10. Solar drying and sun drying of Peppermint.

\section{B. Essential oil content of Lemon Balm and Peppermint:}

Regarding the influence of the drying method on the essential oil content (\%) of the fresh and dried herb, the data in Table (1) indicate that solar 
drying method proved to be the most proper one in this regard followed by natural drying.

Table (1): Values of essential oil (\%) of the Lemon Balm and Peppermint:

\begin{tabular}{|l|c|c|}
\hline Item & Lemon Balm & Peppermint \\
\hline Fresh plants & 2.3 & 5.1 \\
Dried plants by Solar drying & 1.66 & 4.14 \\
Dried plants by Natural drying & 1.02 & 3.05 \\
& & \\
\hline
\end{tabular}

C. Chlorophylls "a" and "b" contents of Lemon Balm and Peppermint:

It could be seen from table (2) that, the chlorophylls content "a" and "b" of the all dried herbs by hybrid solar dryer was higher than natural drying methods. Insignificant difference could be noticed between the solar and natural drying methods regarding their effect on the chlorophyll content.

Table (2): Values of the chlorophylls "a" and "b" contents (microgram/g) of the Lemon Balm and Peppermint:

\begin{tabular}{|c|c|c|}
\hline Item & Chlorophyll "a" & Chlorophyll "b" \\
\hline \multicolumn{3}{|c|}{ Lemon Balm } \\
\hline Fresh plants & 34.34 & 56.23 \\
\hline Dried plants by Solar drying & 25.64 & 43.26 \\
\hline Dried plants by Natural drying & 11.82 & 23.55 \\
\hline \multicolumn{3}{|c|}{ Peppermint } \\
\hline Fresh plants & 32.42 & 54.31 \\
\hline Dried plants by Solar drying & 24.4 & 41.6 \\
\hline Dried plants by Natural drying & 11.02 & 22.15 \\
\hline
\end{tabular}

\section{CONCLUSION}

Temperature in the dryer was higher than the ambient temperature and it could be maintained as desired. Moisture reduction was higher in solar dryer than that of open sun drying. It took about 10 hours and 33 hours to reduce the moisture content of Melissa from 72 to $9 \%$ (wb) in the solar dryer and to reduce it to $17 \%$ (wb) by sun drying method, respectively. The capacity of the dryer was about $16-20 \mathrm{~kg}$ of fresh lemon balm (Melissa) per batch. Moisture content of Peppermint was reduced from $70 \%$ (wb) to $8 \%$ (wb) in 12 hours by solar and sun drying method respectively in 51 hours to reduce it to $10 \%(\mathrm{wb})$. The loading capacity of 
Peppermint was about 16-20 kg per batch. The colour of samples dried in the dryer was better than the samples dried in the sun. The oil content and physical appearance of the samples dried in the dryer was better than that of sun drying samples.

The dryer can also be used with an auxiliary heat source with the dryer when adverse weather conditions exist. Using the water tank with the solar dryer, about $15-20^{\circ} \mathrm{C}$ can be stored in water during the time of sunshine. During the night, the system transfers the stored heat from the water to the air inside the solar dryer and controls the air temperature through the drying process at night.

\section{RECOMMANDITIONS}

- This unit of tunnel dryer can be used to determine the moisture diffusivity of other plants, fruits, and vegetables.

- This dryer may be recommended for drying of fruits and vegetables in developing countries.

\section{REFERENCES}

Abdel-Galil, H. S. and Tarhuni, M. M. 2005. Solar drying of medicinal plants under Libyan conditions. Misr J. Agric. Eng., 22 (4): 171191.

Abdel-Ghaffar, E. 1986. Rock-beds heat surge for solar heated air. Misr J. Agric. Eng., 3 (3): $33-42$.

Amer, B. M. A. 2006. A hybrid solar fruit drying system for small-scale farmers in subtropical and tropical countries. zur Erlangung des akademischen Grades doctor rerum agriculturarum (Dr. rer. agr.), eingereicht an der Landwirtschaftlich-Gärtnerischen Fakultät der Humboldt-Universität zu Berlin.

Amer, B. M. A., Hossain, M. A. and Gottschaslk, K. 2010. Design and performance evaluation of a new hybrid dryer for banana. Energy Conversion and Management, 51(4): 813-820.

Awady, M. N., Mohamed, S. A., EL-Sayed, S. A. and Hassanain A. A. 1993. Utilization of solar energy for drying processes of agricultural products. Misr J. Agric. Eng. 10 (43): 794- 804.

Bala, B. K. 2000. Adaptive research on solar drier for drying mango, pineapple and fish. Final Research Report, Department of Farm Power and Machinery, Bangladesh Agricultural University, Mymensingh. 
Bennamoun, L. and Belhamri, A. 2003. Design and simulation of a solar dryer for agricultural products. Journal of Food Engineering. 59: 259-266.

Esper, A. and Mühlbauer, W. 1998. Solar drying-an effective means of food preservation. Renewable Energy. 15: 95-100.

Ghanem, T. H. 1998. Solar energy utilization, specifically on drying or sterilization of animal manure under Egyptian conditions for use as protein supplement in animal feed. Ph. D. Th., Fac. of Agric. ELAzhar Univ. Vol. 76, 95- 199.

Ghazanfari, A.; Tabil, L. and Sokhansanj, S. 2003. Evaluating a solar dryer for in-shell drying of split pistachio nuts. Drying Technology. 21(7): 1357-1368.

Hossain, M. A.; Woods, J. L. and Bala, B. K. 2007. Single-layer drying characteristics and colour kinetics of red chilli. International Journal of Food Science and Technology. 42(11): 1367-1375.

Hossain, M. A. and Bala, B. K. 2007. Drying of hot chilli using solar tunnel dryer. Solar Energy. 81(1):85-92.

Hossain, M. A., Amer, B. M. A. and Gottschalk, K. 2008. Hybrid solar dryer for quality dried tomato. Drying Technology. 26: 1591-1601.

Kassem, A. M., El-batawi, I. E. and Mahassen M. A. Sidky. 2006. Effect of solar energy and other drying methods on quality of some medicinal plants. The $14^{\text {th }}$ Annual Conference of the Misr Society of Agric. Eng.

Maria, T. 1977. Applications of solar energy for heating and cooling of buildings. ASHRAE GRP: 170.

Miller, W. M. 1983. Energy storage via desiccants for food/agricultural applications. Energy in Agriculture. Vol. 2(4), pp. 341-354.

Mühlbauer, W. 1986. Present status of solar crop drying. Energy in Agriculture. 5: 121-127.

Nedkov, N. K. and Georgiev, G. V. 1991. A study of different irrigation practices used for Mentha piperita in Bulgaria. Journal of Essential oil research. 3 (6): $435-440$.

Paakkonen, K., Havento, J., Galambosi, B. and M. Pyykkonen. 1999. Infared drying of herbs. Agricultural and food Science in Finland. 8 (1): $19-27$. 
Sabbah, M. A. 1986. Design and thermal performance of a solar drying system in Riyadh area. J. Coll. Agric. King Saud Univ. Vol. 8(1), pp. 49-75. Riyadh, Saudi Arabia.

Sabbah, M. A., Shokr, A. Z., Soliman, S. N. and Gomaa, A. E. 1999. Thermal performance of different designs of solar air heaters. Misr J. Agric. Eng. 16 (3): 479-501.

Singh, R. K., Lund, D. B. and Buelow, F. H. 1983. Application of Solar Energy in Food processing. II. Food Dehydration. Transactions of the ASAE. 26(5), pp. 1569-1574.

\section{Part of a Book :}

Müller, J., and Heindl, A. 2006. Drying of medicinal plants. In Medicinal and aromatic plants-agricultural, commercial, ecological, legal, pharmacological and social aspects, pp 237-252, Berlin, Heidelberg, Germany: Springer-Verlag.

\section{الملخص العربي}

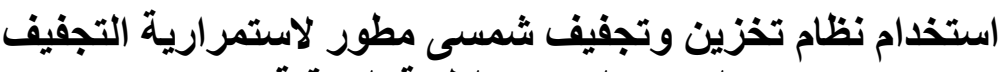

\section{لبعض النباتات الطبية الورقية}

\section{د. باهر محمود أحمد عامر}

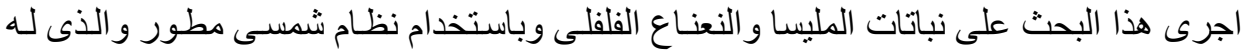

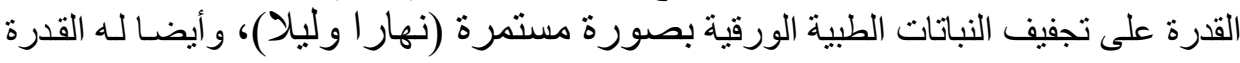

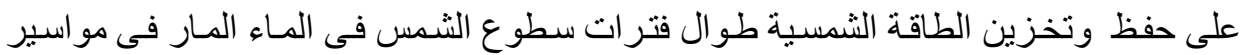

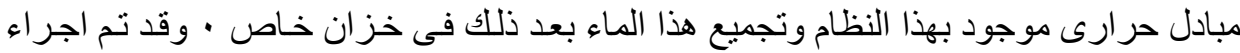

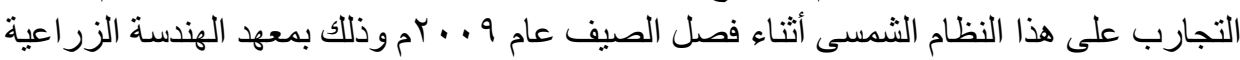
بمدينة بو تسدام بألمانيا.

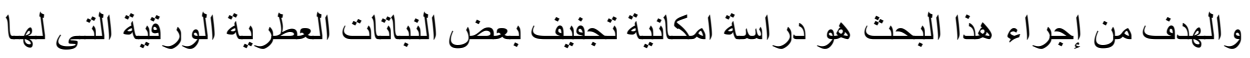

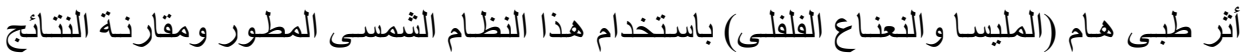

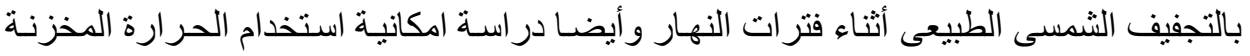

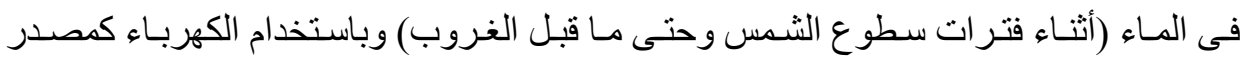

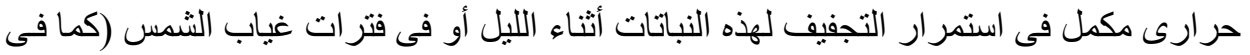

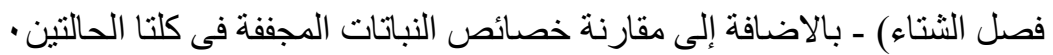

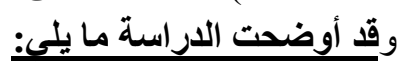

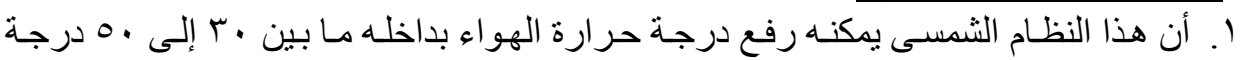

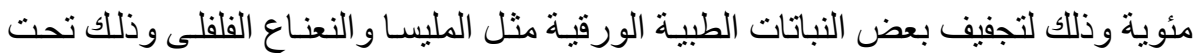
الظروف الجوية لموسم الصيف بألمانيا

*مدرس الهندة الزراعية ـ كلية الزراعة ـ جامعة القاهرة 


\section{PROCESS ENGINEERING}

Y. تم تجفيف نباتـات المليسـا باستخدام هذا النظـام الشمسى (أثتـاء فتر ات النهار ) وذلك للافعـة

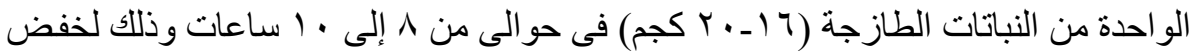

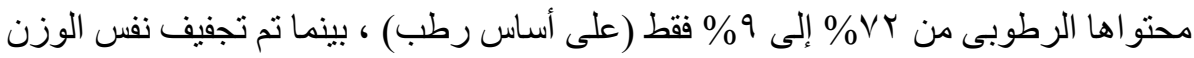

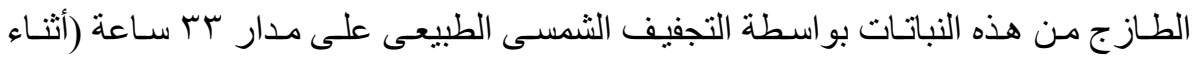

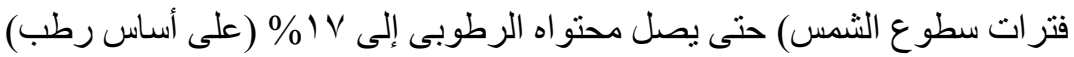

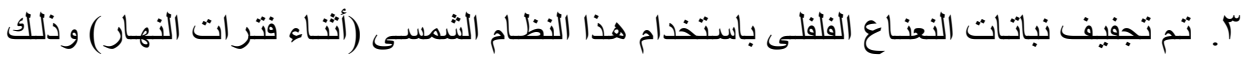

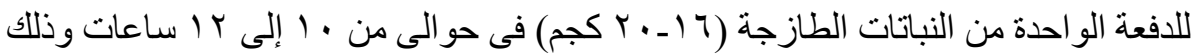

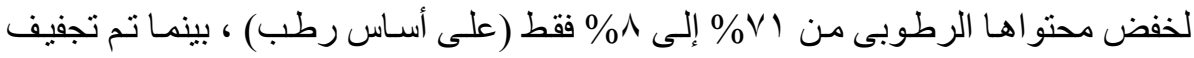

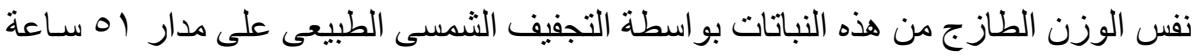
(أثناء فترات سطوع الثمس) حتى يصل محتو اه الرطوبى إلى • (

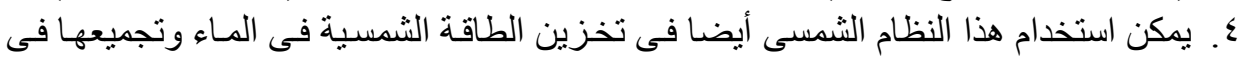

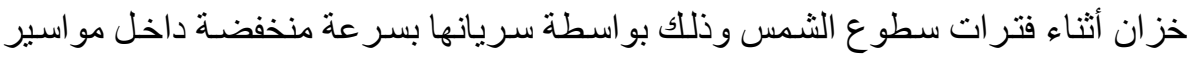

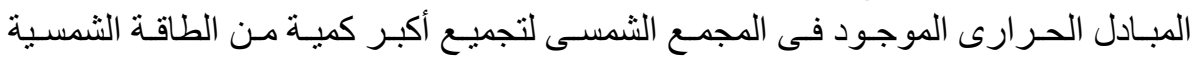

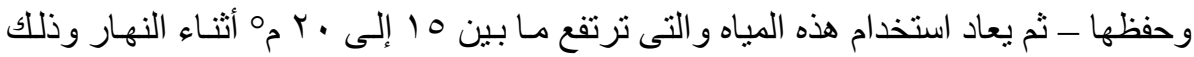

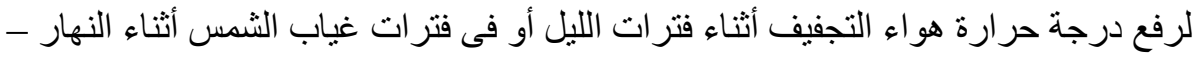
كما يمكن تثبيت درجة حر ارة المياه الدافئة أثناء الليل عن طريق استخدام السخانات الكهربية

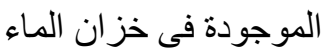

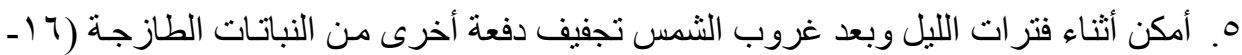

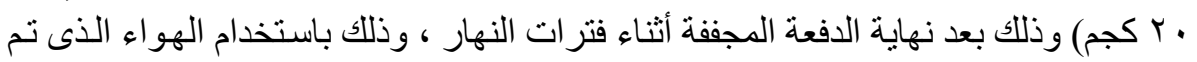

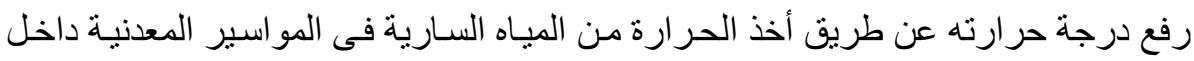

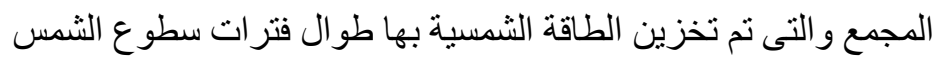
7 ا و وقد وجد أن التجفيف باستخدام الطاقة الثمسية مناسب لتجفيف النباتات العطريـة نظر التقليل

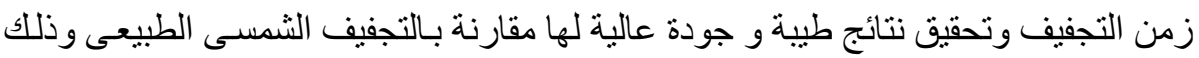

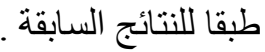

\section{التوصيات}

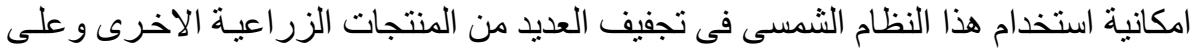

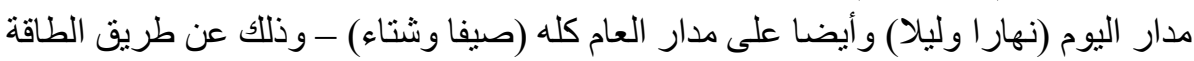

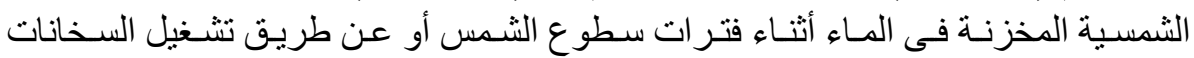
المساعدة الموجودة في خز ان الماء كما يمكن استخدام هذا النظام الثمسى فى التجفيف لكثير ا من المنتجـات الزر اعيـة وبصـورة

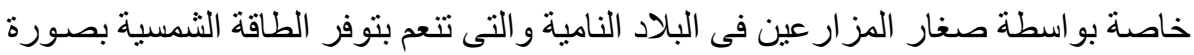
كبيرة كما فى مصر و الدول العربية 